\title{
Meta-Analysis of the Association between Vitamin D Receptor Polymorphisms and the Risk of Autoimmune Thyroid Disease
}

\author{
Xue-Ren Gao and Yong-Guo Yu \\ Department of Pediatric Endocrinology/Genetics, Shanghai Institute for Pediatric Research, Xinhua Hospital, School of Medicine, \\ Shanghai Jiao Tong University, Shanghai 200092, China
}

Correspondence should be addressed to Yong-Guo Yu; yuyongguo@shsmu.edu.cn

Received 17 September 2017; Revised 1 December 2017; Accepted 17 December 2017; Published 22 March 2018

Academic Editor: Jack Wall

Copyright (c) 2018 Xue-Ren Gao and Yong-Guo Yu. This is an open access article distributed under the Creative Commons Attribution License, which permits unrestricted use, distribution, and reproduction in any medium, provided the original work is properly cited.

\begin{abstract}
The association between vitamin D receptor ( VDR) polymorphisms (rs731236, rs1544410, rs2228570, and rs7975232) and the risk of autoimmune thyroid disease (AITD) had been investigated in previous studies. However, the results of these studies remained controversial. Thus, a meta-analysis was performed to derive a more precise conclusion. All related articles were systematically searched by PubMed, Embase, Google Scholar, and Chinese National Knowledge Infrastructure (CNKI). The pooled odds ratios (ORs) with 95\% confidence intervals (CIs) were calculated to assess the strength of association. The overall results indicated that $V D R$ rs731236 and rs2228570 polymorphisms were significantly associated with a reduced risk of AITD. However, a stratification analysis based on clinical types showed that VDR rs731236 and rs2228570 polymorphisms were associated only with a reduced risk of HT. A stratification analysis by ethnicity showed that $V D R$ rs731236 polymorphism was significantly associated with a reduced risk of AITD in Asian and African populations. VDR rs 2228570 polymorphism was associated with a reduced risk of AITD in Asian populations. VDR rs1544410 polymorphism was associated with a reduced risk of AITD in European and African populations, but with an increased risk of AITD in Asian populations. VDR rs7975232 polymorphism was significantly associated with an increased risk of AITD in African populations. In conclusion, the present study suggested that VDR rs731236, rs1544410, rs2228570, and rs7975232 polymorphisms were significantly associated with AITD risk. However, more well-designed studies should be performed to verify the current results.
\end{abstract}

\section{Introduction}

Autoimmune thyroid disease (AITD), mainly including Graves' disease (GD) and Hashimoto's thyroiditis (HT), is an organ-specific autoimmune disease and affects up to $5 \%$ of the general population $[1,2]$. Although the pathogenesis of AITD is still unknown, it is generally acknowledged that environmental factors and the intrinsic genetic predisposition of an individual play critical roles in the occurrence of the disease [3]. Environmental factors, such as viral infections, irradiation, drugs, and iodine intake, may involve interference with thyroid function, direct toxic effects on thyrocytes, immune stimulation, or other immunomodulatory effects $[3,4]$. However, it is difficult to directly link an environmental exposure with AITD due to the intervention of genetic factors. Increasing evidence suggests that single- nucleotide polymorphisms (SNPs) in AITD-related genes can influence individual predisposition to the disease [5-7].

Vitamin $\mathrm{D}$ is a fat-soluble vitamin and is activated in the liver and kidney [8]. Activated vitamin $\mathrm{D}\left[1,25(\mathrm{OH})_{2} \mathrm{D}\right]$ can promote the differentiation of monocytes and inhibit the maturation of dendritic cells [9]. Furthermore, it can also suppress the production of cytokines, such as interleukin-1, interleukin-2, interleukin-6, and tumor necrosis factor [10]. These cytokines play important roles in the development of lymphocytes, which are believed to be involved in the pathogenesis of autoimmune diseases. The immunomodulatory actions of $1,25(\mathrm{OH})_{2} \mathrm{D}$ are mediated by its binding to vitamin $\mathrm{D}$ receptor (VDR), which belongs to the family of trans-acting transcriptional regulatory factors and is widely expressed in various immune cell subsets, including lymphocytes, macrophages, and several endocrine cells [11]. The gene 


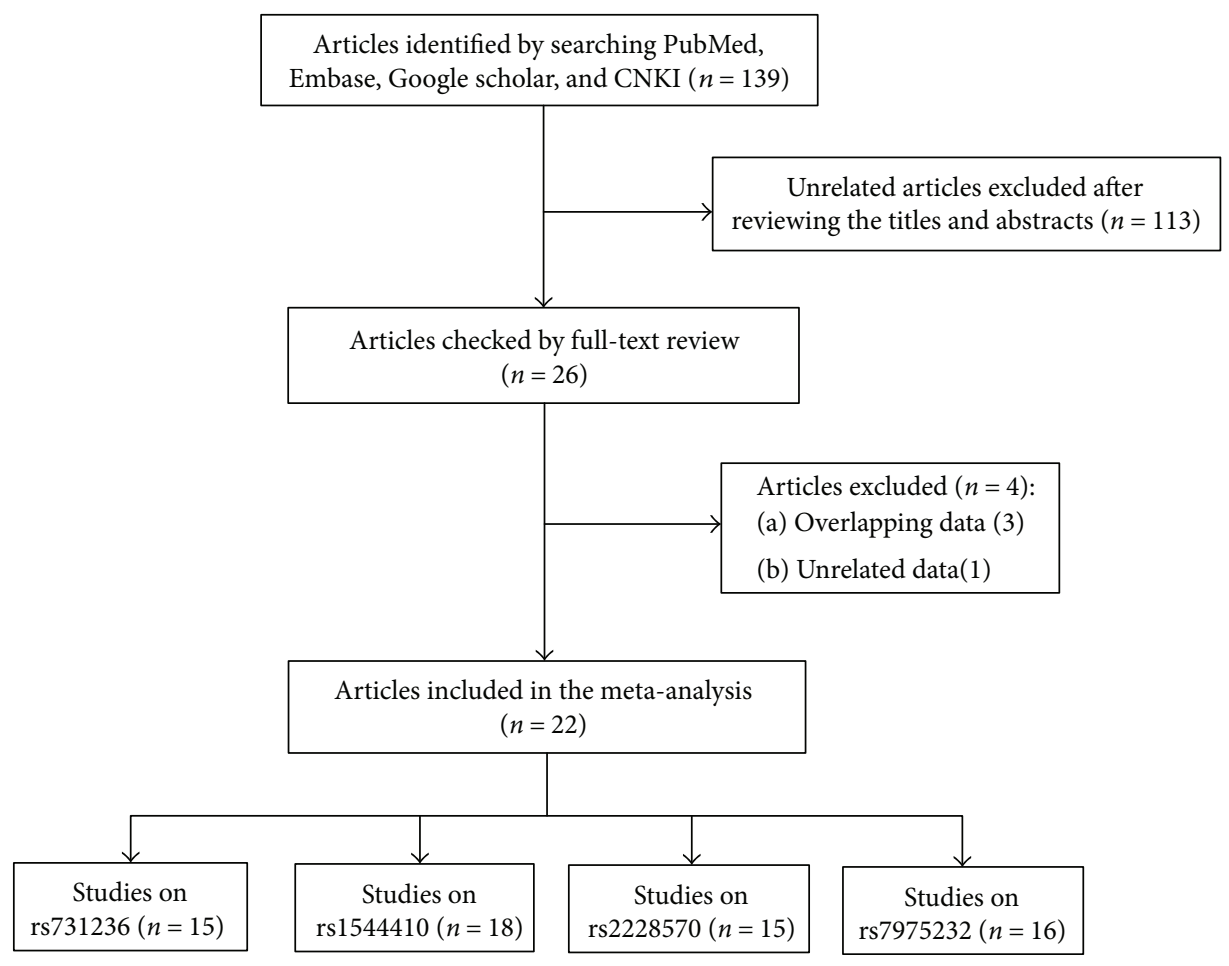

FIGURE 1: The flowchart for identifying eligible studies.

encoding VDR contains 14 exons and spans approximately 75 kilobases on chromosome 12q13.11. Many SNPs have been identified in the VDR gene [12]. Among them, the association of VDR rs731236, rs1544410, rs2228570, and rs7975232 polymorphisms with AITD risk has been widely reported [13-34]. However, the results are inconsistent and ambiguous. Furthermore, considering that a single-center pilot study with small sample sizes may possess low statistical power, we performed a meta-analysis of all eligible studies to obtain a more precise conclusion.

\section{Methods}

2.1. Search Strategy. All related articles were obtained by systematically searching PubMed, Embase, Google Scholar, and Chinese National Knowledge Infrastructure (CNKI). The search keywords were as follows: "vitamin D receptor OR VDR," "polymorphism OR genetic variation OR genetic variant," and "autoimmune thyroid disease OR AITD OR thyroid." There were no limitations on language and year of publication. The last search was updated on August 28, 2017. Furthermore, the references of all related articles were also retrieved to find other eligible studies.

2.2. Inclusion and Exclusion Criteria. All eligible studies must meet the following inclusion criteria: (a) case-control studies; (b) evaluation of the association between VDR polymorphisms (rs731236, rs1544410, rs2228570, and rs7975232) and AITD risk; and (c) available genotype/allele frequencies. In addition, the exclusion criteria were as follows: (a) letters, reviews, and case reports and (b) duplicate publication. If multiple studies had overlapping data, only those with complete data were included.

2.3. Data Extraction. Two authors independently reviewed the related articles and extracted the following data: first author's name, year of publication, region, ethnicity, genotyping methods, the number of cases and controls, and genotype/allele frequency. Any disagreement was resolved by discussion with each other.

2.4. Statistical Analysis. Hardy-Weinberg equilibrium (HWE) in the control group of each study was calculated by chi-square goodness-of-fit test, and $P_{\mathrm{HWE}}<0.05$ was considered as a deviation from HWE. The strength of the association between VDR polymorphisms (rs731236, rs1544410, rs2228570, and rs7975232) and AITD risk was evaluated by the pooled odds ratios (ORs) with $95 \%$ confidence intervals (CIs). The significance of the pooled ORs was assessed by the $Z$ test, and $P_{Z}<0.05$ was considered statistically significant. The chi-square based Q-test was used to investigate the between-study heterogeneity. If $P_{\mathrm{H}}<0.1$ indicated the existence of between-study heterogeneity, the random-effect model was used to calculate the pooled ORs; otherwise, the fixed-effect model was applied for the analysis. A sensitivity analysis was conducted by omitting one study each time to estimate the stability of the result. Publication bias was determined by Begg's funnel plot and Egger's test. A symmetric funnel plot and $P$ value of Egger's test more than 0.05 indicated the lack of publication bias. All statistical tests were performed using Review Manager 5.2 (The Nordic Cochrane Centre, The Cochrane Collaboration, Copenhagen) and 
TABLE 1: The main characteristics of all included articles.

\begin{tabular}{|c|c|c|c|c|c|c|c|}
\hline First author & $\begin{array}{c}\text { Year of } \\
\text { publication }\end{array}$ & Region & Ethnicity & Cases & Controls & $\begin{array}{l}\text { Genotyping } \\
\text { method }\end{array}$ & Polymorphisms \\
\hline Giovinazzo [13] & 2016 & Italy & European & $100 \mathrm{HT}$ & 100 & PCR-RFLP & $\begin{array}{c}\text { rs731236, rs7975232, } \\
\text { rs1544410 }\end{array}$ \\
\hline Guleryuz [33] & 2016 & Turkey & Asian & $136 \mathrm{HT}$ & 50 & PCR-RFLP & rs731236, rs2228570 \\
\hline Long [14] & 2015 & China & Asian & $260 \mathrm{GD}$ & 221 & PCR-RFLP & rs7975232 \\
\hline Meng [15] & 2015 & China & Asian & $\begin{array}{l}417 \mathrm{GD} \text { and } \\
250 \mathrm{HT}\end{array}$ & 301 & $\begin{array}{l}\text { MALDI- } \\
\text { TOF-MS }\end{array}$ & $\begin{array}{l}\text { rs731236, rs7975232, } \\
\text { rs2228570, rs1544410 }\end{array}$ \\
\hline Djurovic [16] & 2015 & Serbia & European & $44 \mathrm{HT}$ & 32 & PCR-RFLP & $\begin{array}{c}\text { rs731236, rs7975232 } \\
\text { rs2228570 }\end{array}$ \\
\hline Inoue [17] & 2014 & Japan & Asian & $\begin{array}{c}139 \text { GD and } \\
116 \mathrm{HT}\end{array}$ & 76 & PCR-RFLP & $\begin{array}{l}\text { rs731236, rs7975232, } \\
\text { rs2228570, rs1544410 }\end{array}$ \\
\hline Yu [18] & 2013 & China & Asian & $75 \mathrm{HT}$ & 80 & PCR-RFLP & rs 1544410 \\
\hline Yazici [19] & 2013 & Turkey & Asian & $111 \mathrm{HT}$ & 159 & PCR-RFLP & $\begin{array}{l}\text { rs731236, rs7975232, } \\
\text { rs2228570, rs1544410 }\end{array}$ \\
\hline El Gawad [34] & 2012 & Egypt & African & $90 \mathrm{GD}$ & 55 & PCR-RFLP & $\begin{array}{l}\text { rs731236, rs7975232, } \\
\text { rs1544410 }\end{array}$ \\
\hline Hong [20] & 2011 & China & Asian & $82 \mathrm{HT}$ & 80 & PCR-RFLP & rs2228570 \\
\hline Huo [21] & 2010 & China & Asian & $\begin{array}{c}120 \mathrm{GD} \text { and } \\
115 \mathrm{HT}\end{array}$ & 120 & PCR-RFLP & rs 1544410 \\
\hline $\begin{array}{l}\text { Horst-Sikorska } \\
{[22]}\end{array}$ & 2008 & Poland & European & $75 \mathrm{GD}$ & 163 & PCR-RFLP & $\begin{array}{l}\text { rs731236, rs7975232, } \\
\text { rs2228570, rs1544410 }\end{array}$ \\
\hline Maalej [23] & 2008 & Tunisia & African & 100 AITD & 100 & PCR-RFLP & $\begin{array}{l}\text { rs731236, rs2228570 } \\
\text { rs1544410 }\end{array}$ \\
\hline Jing [24] & 2008 & China & Asian & $115 \mathrm{HT}$ & 120 & PCR-RFLP & rs 1544410 \\
\hline Stefanić [25] & 2008 & Croatia & European & $145 \mathrm{HT}$ & 145 & PCR-RFLP & $\begin{array}{c}\text { rs731236, rs7975232, } \\
\text { rs1544410 }\end{array}$ \\
\hline Chen [31] & 2007 & Taiwan & Asian & $88 \mathrm{GD}$ & 90 & PCR-RFLP & rs2228570 \\
\hline Lin [26] & 2006 & Taiwan & Asian & $109 \mathrm{HT}$ & 90 & PCR-RFLP & rs 2228570 \\
\hline Ramos-Lopez [27] & 2005 & $\begin{array}{c}\text { Germany, } \\
\text { Poland, Serbia }\end{array}$ & European & 789 GD & 823 & PCR-RFLP & $\begin{array}{l}\text { rs731236, rs7975232, } \\
\text { rs2228570, rs1544410 }\end{array}$ \\
\hline Stefanić [28] & 2005 & Croatia & European & $110 \mathrm{GD}$ & 99 & PCR-RFLP & $\begin{array}{c}\text { rs731236, rs7975232 } \\
\text { rs1544410 }\end{array}$ \\
\hline Kang [29] & 2005 & China & Asian & 102 GD & 120 & PCR-RFLP & rs7975232, rs1544410 \\
\hline Collins [32] & 2004 & $\begin{array}{l}\text { United } \\
\text { Kingdom }\end{array}$ & European & 768 GD & 864 & PCR-RFLP & $\begin{array}{l}\text { rs731236, rs7975232, } \\
\text { rs2228570, rs1544410 }\end{array}$ \\
\hline Ban $[30]$ & 2000 & Japan & Asian & 180 GD & 195 & PCR-RFLP & $\begin{array}{c}\text { rs7975232, rs2228570, } \\
\text { rs } 1544410\end{array}$ \\
\hline
\end{tabular}

PCR-RFLP: polymerase chain reaction-restriction fragment length polymorphism; MALDI-TOF-MS: matrix-assisted laser desorption ionization-time of flight mass spectrometry.

the STATA 12.0 software (Stata Corporation, College Station, TX).

\section{Results}

3.1. Study Selection and Characteristics. The flowchart for identifying eligible studies is shown in Figure 1. A total of 139 articles were obtained through an initial search. After reviewing the titles and abstracts of these articles, we excluded 113 unrelated articles. The remaining articles were further checked by a full-text review. Finally, 22 articles met the inclusion criteria and were included in this metaanalysis. The main characteristics of all included articles are shown in Tables 1 and S1. A total of 24 studies from 22 articles assessed the association of $V D R$ polymorphisms and AITD risk. Thereinto, there were 15 studies on rs731236, 18 studies on rs1544410, 15 studies on rs2228570, and 16 studies on rs7975232. All studies used polymerase chain reaction-restriction fragment length polymorphism (PCR-RFLP) method for genotyping except for Meng et al.'s study.

3.2. Quantitative Synthesis. The association between VDR rs731236 polymorphism and AITD risk is shown in Table 2 and Figure 2. In the overall analysis, a significant association was found in homozygote comparison and recessive models (CC versus TT: $\mathrm{OR}=0.67,95 \% \mathrm{CI}$ : $0.48-0.93, P_{Z}=0.02$; CC versus CT $+\mathrm{TT}$ : $\mathrm{OR}=0.80,95 \%$ 


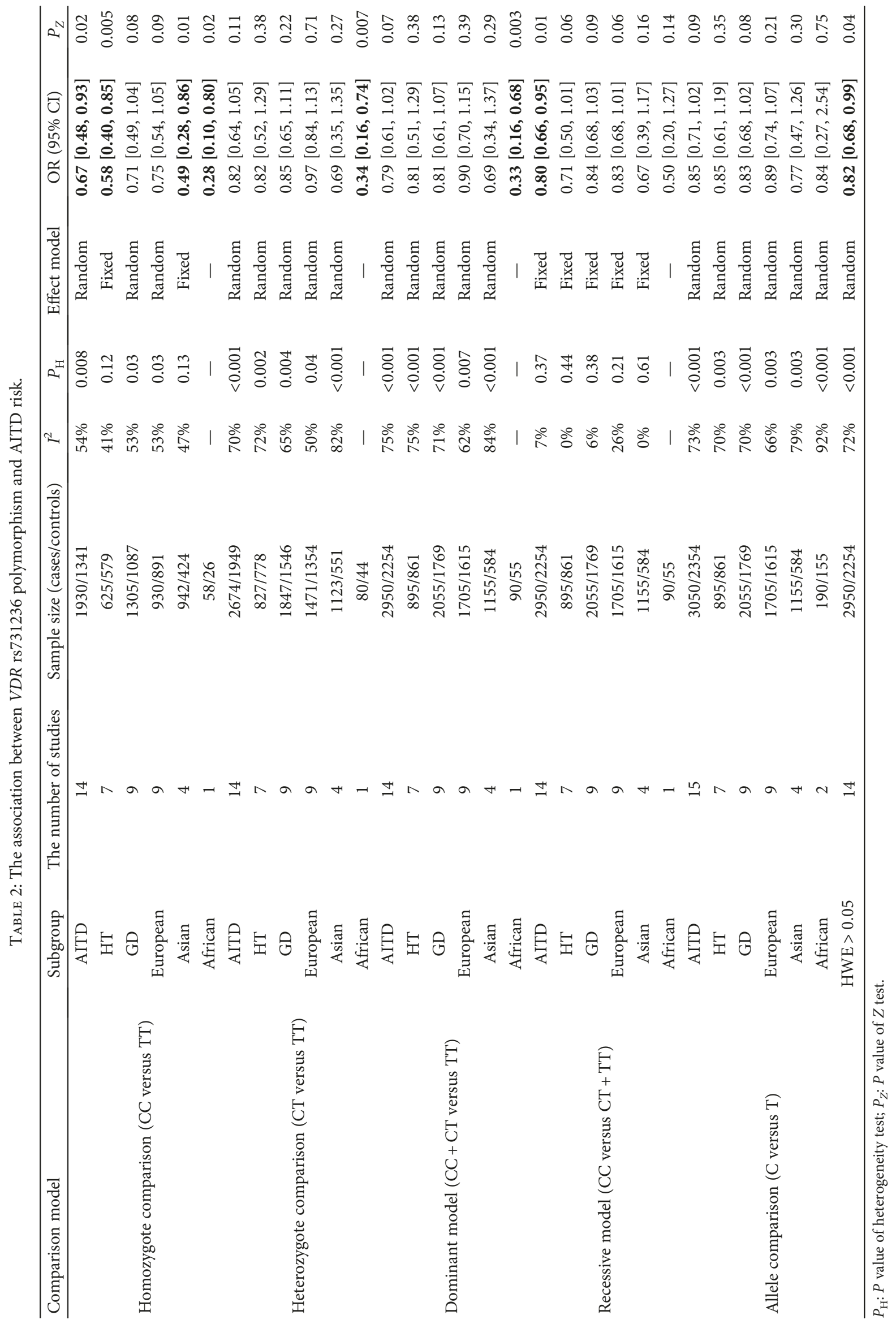




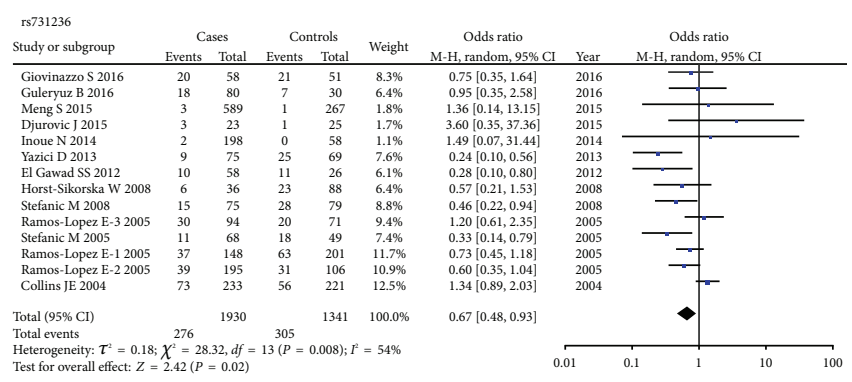

(a) rs731236

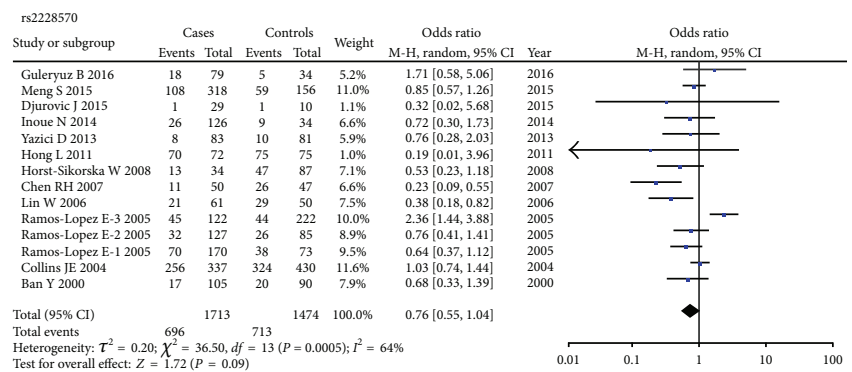

(c) $r s 2228570$

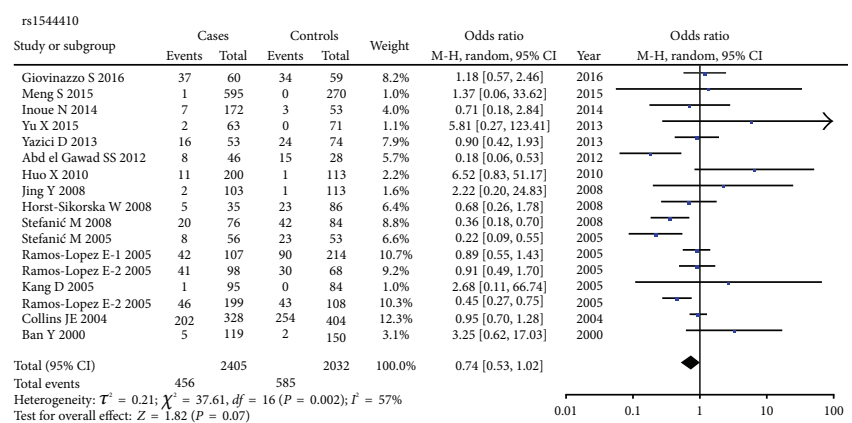

(b) rs1544410

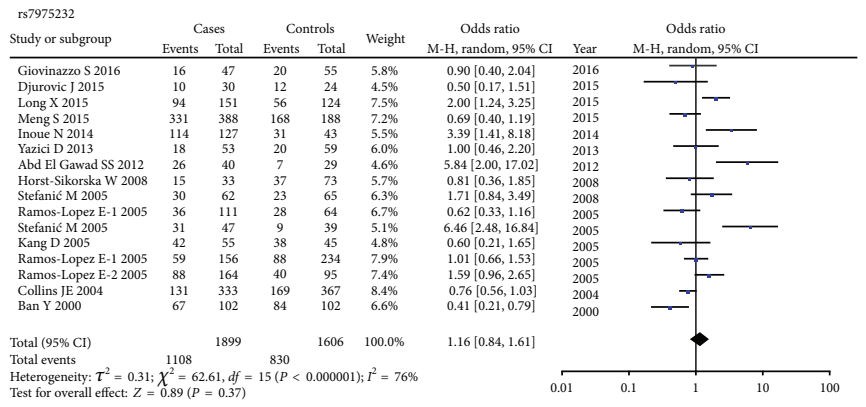

(d) rs7975232

FIGURE 2: Forest plot of the association of VDR polymorphisms with AITD risk in homozygote comparison model.

CI: $\left.0.66-0.95, P_{Z}=0.01\right)$. In the stratification analysis based on clinical types, a significant association of $V D R$ rs731236 polymorphism with HT risk was found in the homozygote comparison model (CC versus TT: OR = 0.58, 95\% CI: $\left.0.40-0.85, P_{Z}=0.005\right)$. In the subgroup analysis by ethnicity, a significant association was found in Asian (CC versus TT: OR $=0.49$, 95\% CI: $0.28-0.86$, $P_{Z}=0.01$ ) and African populations (CC versus TT: OR = $0.28,95 \%$ CI: $0.10-0.80, P_{Z}=0.02$; CT versus TT: OR = 0.34, 95\% CI: $0.16-0.74, P_{Z}=0.007 ; \mathrm{CC}+\mathrm{CT}$ versus TT: $\left.\mathrm{OR}=0.33,95 \% \mathrm{CI}: 0.16-0.86, P_{Z}=0.003\right)$. The pooled analysis based on $P_{\mathrm{HWE}}>0.05$ showed a significant association in the allele comparison model $(C$ versus $\mathrm{T}$ : $\mathrm{OR}=$ 0.82, 95\% CI: $\left.0.68-0.99, P_{Z}=0.04\right)$.

The association of VDR rs 1544410 polymorphism with AITD risk is presented in Table 3 and Figure 2. No significant association was observed in the overall analysis and stratification analysis by clinical types. However, a subgroup analysis by ethnicity showed that VDR rs1544410 polymorphism was associated with a reduced risk of AITD in European (AA versus GG: $\mathrm{OR}=0.60,95 \% \mathrm{CI}: 0.46-0.93, P_{Z}=0.02$; AG versus GG: $\mathrm{OR}=0.83,95 \% \mathrm{CI}: 0.71-0.97, P_{Z}=0.02$; $\mathrm{AA}+\mathrm{AG}$ versus $\mathrm{GG}: \mathrm{OR}=0.79,95 \% \mathrm{CI}: 0.68-0.91, P_{Z}=$ 0.002; A versus G: $\mathrm{OR}=0.82,95 \% \mathrm{CI}: 0.69-0.98, P_{Z}=0.02$ ) and African (AA versus GG: $\mathrm{OR}=0.18,95 \% \mathrm{CI}$ : $0.06-0.53$, $P_{Z}=0.002 ; \mathrm{AA}+\mathrm{AG}$ versus GG: $\mathrm{OR}=0.42,95 \% \mathrm{CI}: 0.20-$ $0.90, P_{Z}=0.02$; AA versus $\mathrm{AG}+\mathrm{GG}$ : $\mathrm{OR}=0.26,95 \% \mathrm{CI}$ : $\left.0.10-0.66, P_{Z}=0.005\right)$ populations and with an increased risk of AITD in Asian populations (AG versus GG: OR = 1.34, 95\% CI: $1.08-1.67, P_{Z}=0.008$; AA + AG versus GG:
$\mathrm{OR}=1.41,95 \% \mathrm{CI}: 1.05-1.90, P_{Z}=0.02 ; \mathrm{A}$ versus $\mathrm{G}: \mathrm{OR}=$ 1.41, 95\% CI: $\left.1.05-1.90, P_{Z}=0.02\right)$. The pooled analysis based on $P_{\mathrm{HWE}}>0.05$ showed that VDR rs 1544410 polymorphism was associated with a reduced risk of AITD (AA versus GG: $\left.\mathrm{OR}=0.66,95 \% \mathrm{CI}: 0.45-0.98, P_{Z}=0.04\right)$.

The association between VDR rs2228570 polymorphism and AITD risk is shown in Table 4 and Figure 2. A significant association was observed in the overall analysis (CT versus CC: $\mathrm{OR}=0.73,95 \% \mathrm{CI}: 0.56-0.95, P_{Z}=0.02 ; \mathrm{TT}+\mathrm{CT}$ versus CC: $\mathrm{OR}=0.71,95 \% \mathrm{CI}: 0.54-0.93, P_{Z}<0.001$; T versus $\mathrm{C}$ : $\left.\mathrm{OR}=0.80,95 \% \mathrm{CI}: 0.68-0.95, P_{Z}=0.01\right)$. A further stratification analysis by clinical types showed a significant association in HT ( $\mathrm{T}$ versus C: $\mathrm{OR}=0.69,95 \% \mathrm{CI}$ : $0.50-0.97$, $P_{Z}=0.03$ ) but not in GD. A subgroup analysis based on ethnicity showed a significant association in Asian populations (TT versus CC: $\mathrm{OR}=0.63,95 \% \mathrm{CI}: 0.42-0.93, P_{Z}=0.02$; TT $+\mathrm{CT}$ versus CC: $\mathrm{OR}=0.65,95 \% \mathrm{CI}: 0.45-0.95, P_{Z}=$ 0.02 ; TT versus CT $+\mathrm{CC}$ : $\mathrm{OR}=0.72,95 \% \mathrm{CI}: 0.58-0.91, P_{Z}$ $=0.005 ; \mathrm{T}$ versus $\mathrm{C}$ : $\mathrm{OR}=0.72,95 \% \mathrm{CI}: 0.56-0.92, P_{Z}=$ 0.008 ), but not in European populations. A stratification analysis by $P_{\text {HWE }}$ value showed a significant association in studies of $P_{\mathrm{H}} \leq 0.05$ (CT versus CC: $\mathrm{OR}=0.48,95 \% \mathrm{CI}$ : 0.36-0.65, $P_{Z}<0.001$; TT $+\mathrm{CT}$ versus $\mathrm{CC}$ : $\mathrm{OR}=0.51,95 \%$ CI: $0.38-0.68, P_{Z}<0.001$; $\mathrm{T}$ versus $\mathrm{C}$ : $\mathrm{OR}=0.72,95 \% \mathrm{CI}$ : $\left.0.55-0.93, P_{Z}=0.01\right)$ but not in studies of $P_{\mathrm{H}}>0.05$.

For VDR rs7975232 polymorphism, no significant association was observed in the overall analysis and stratification analysis by clinical types and $P_{\text {HWE }}$ (Table 5 and Figure 2). However, a stratification analysis by ethnicity showed that $V D R$ rs7975232 polymorphism was associated with an 


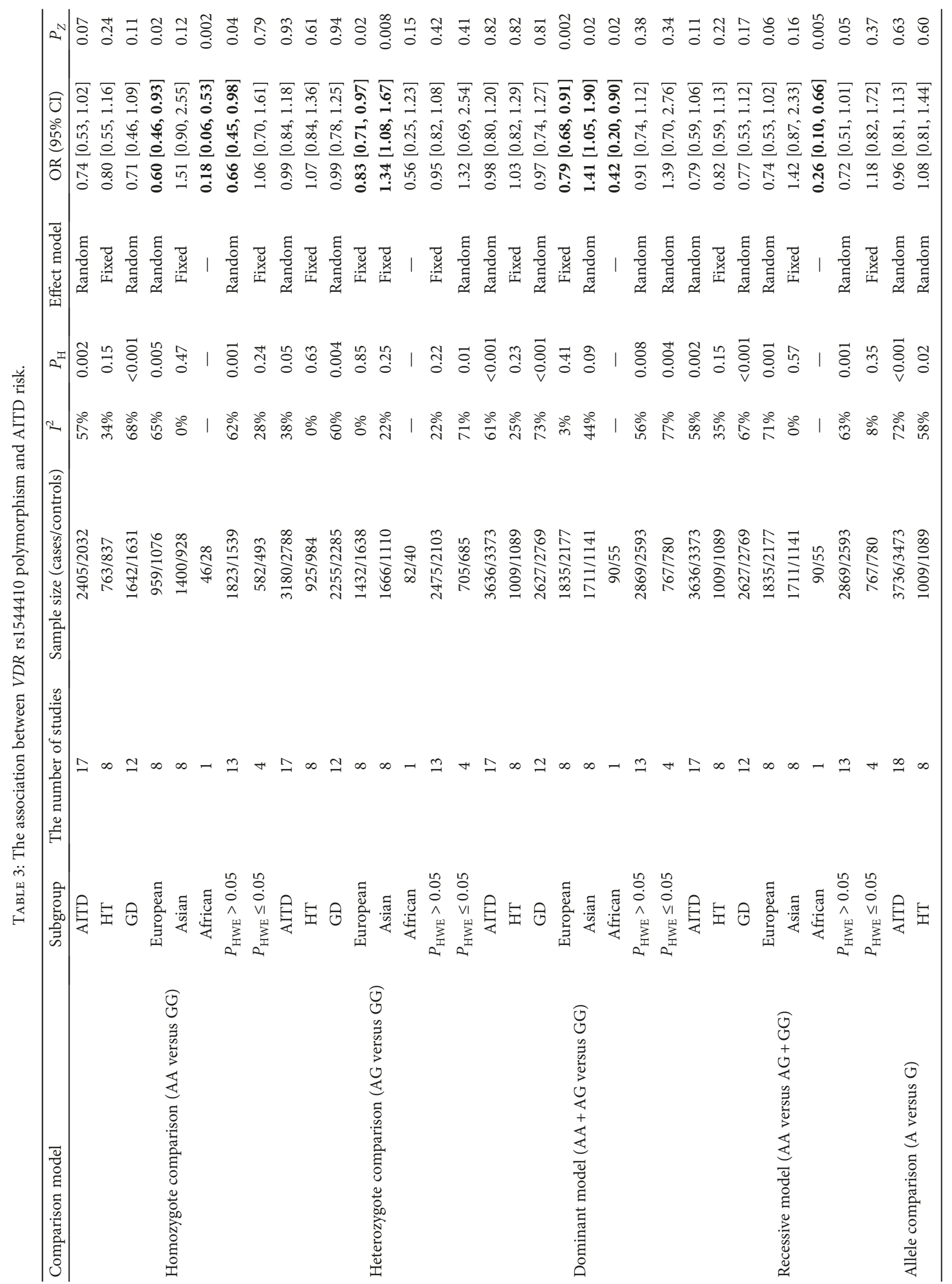




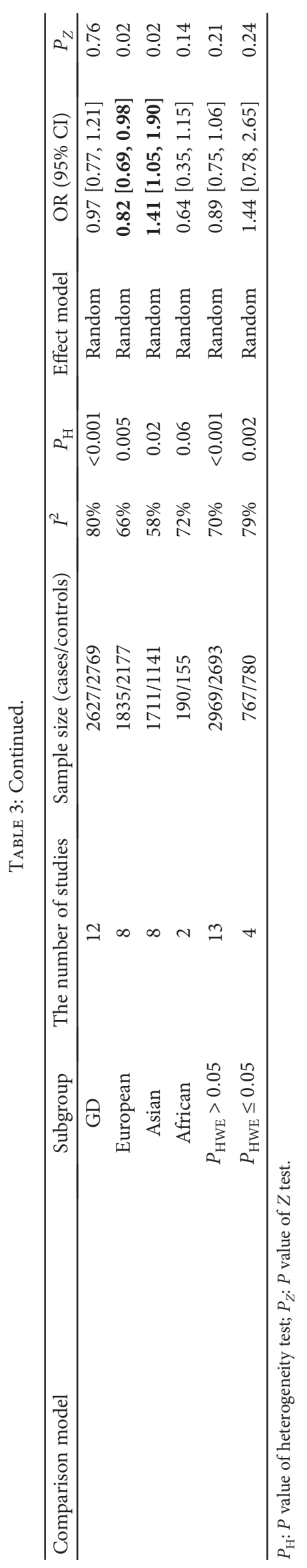




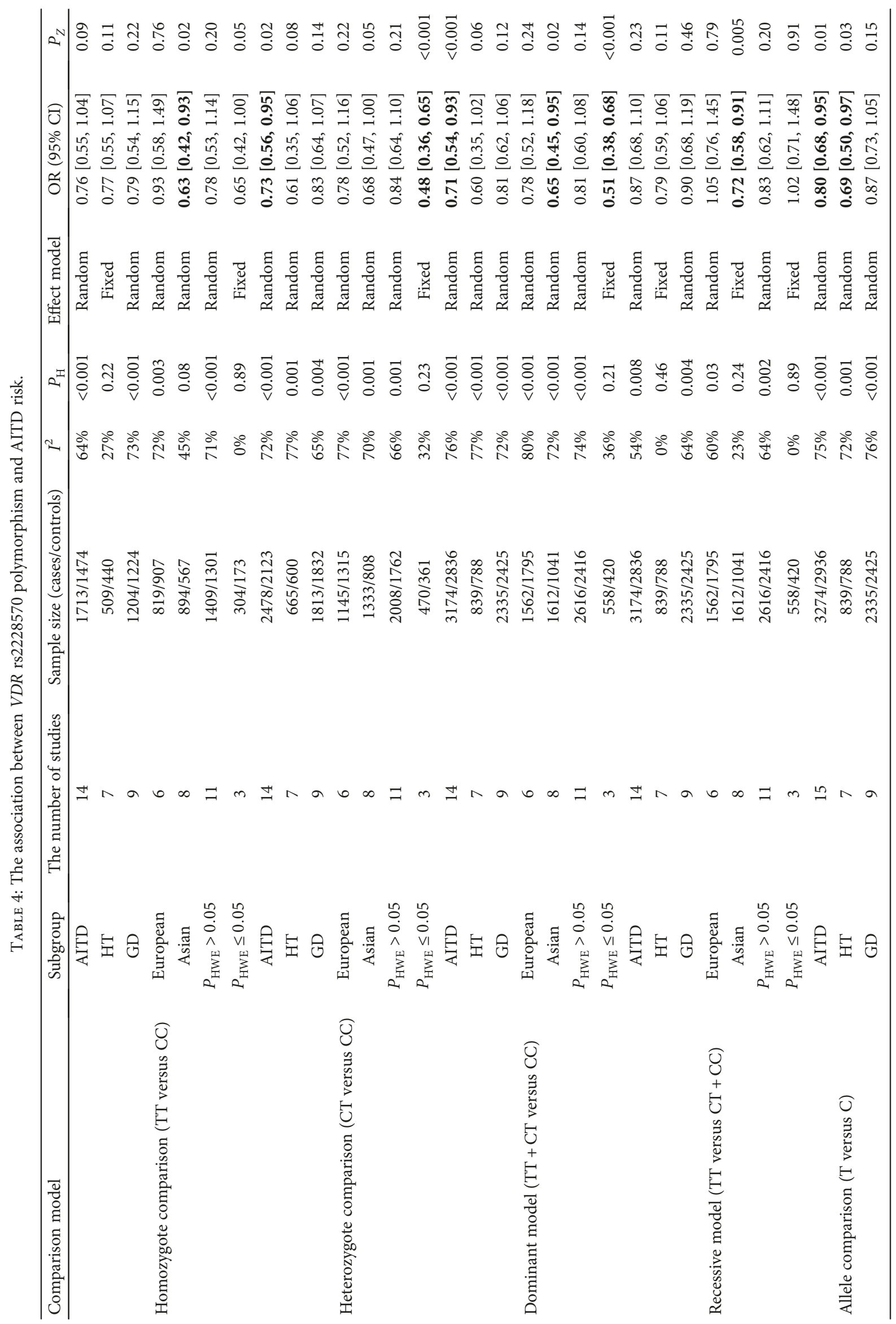




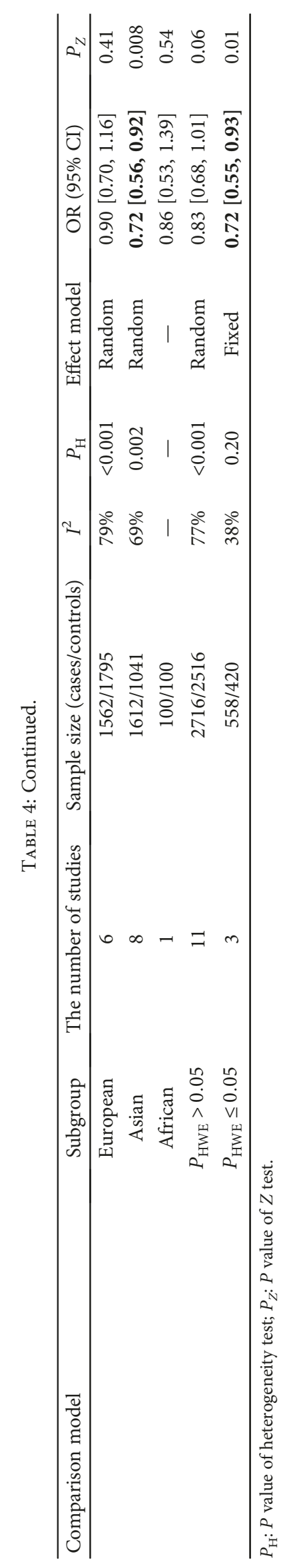




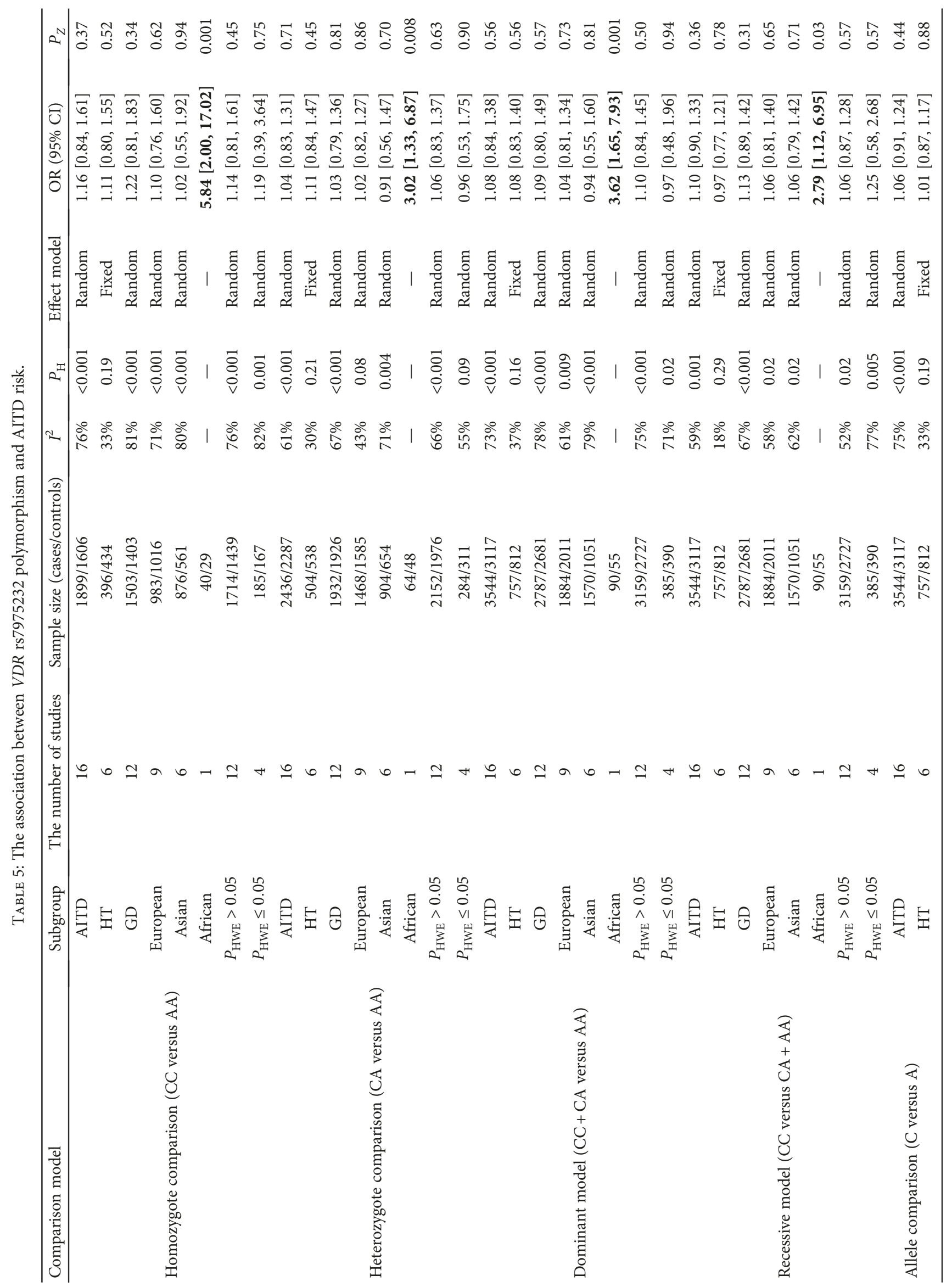




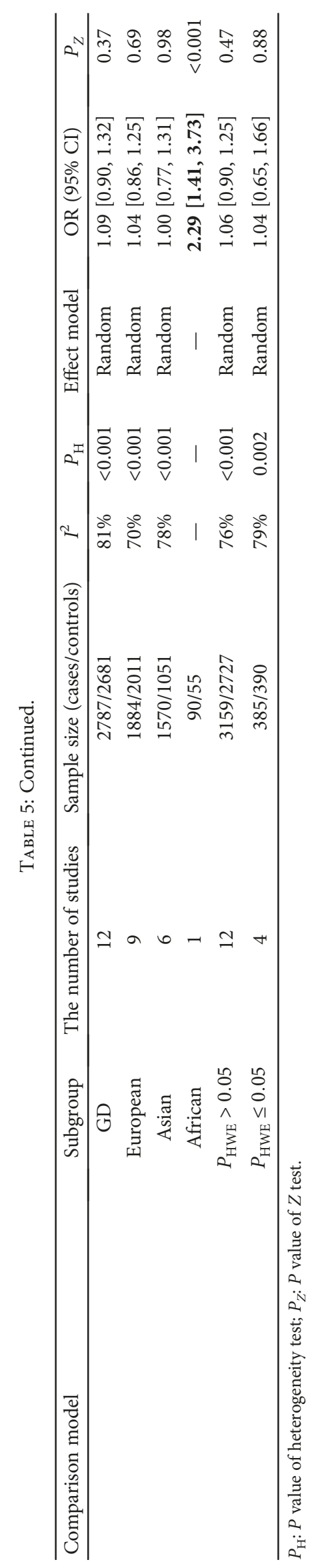




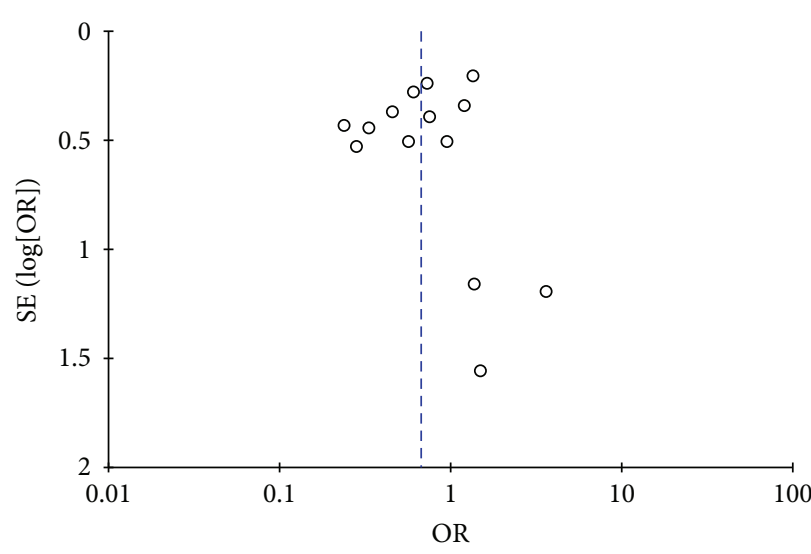

(a) rs731236

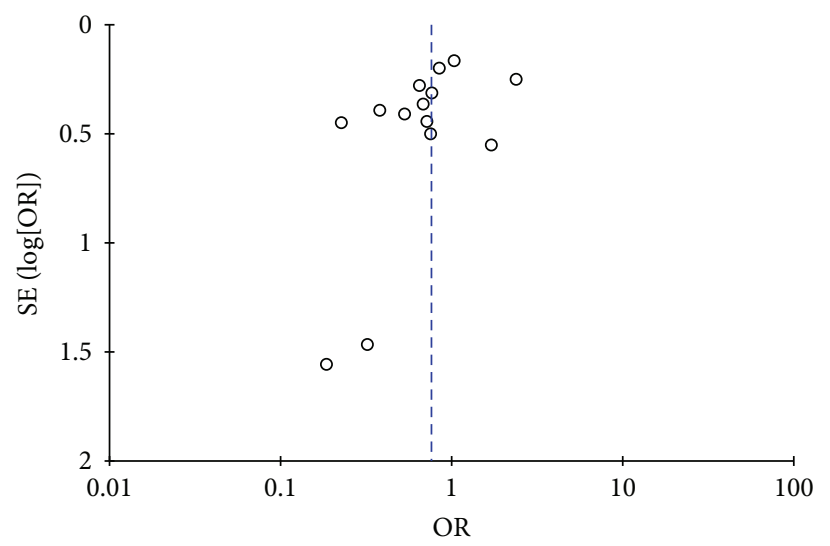

(c) $\mathrm{rs} 2228570$

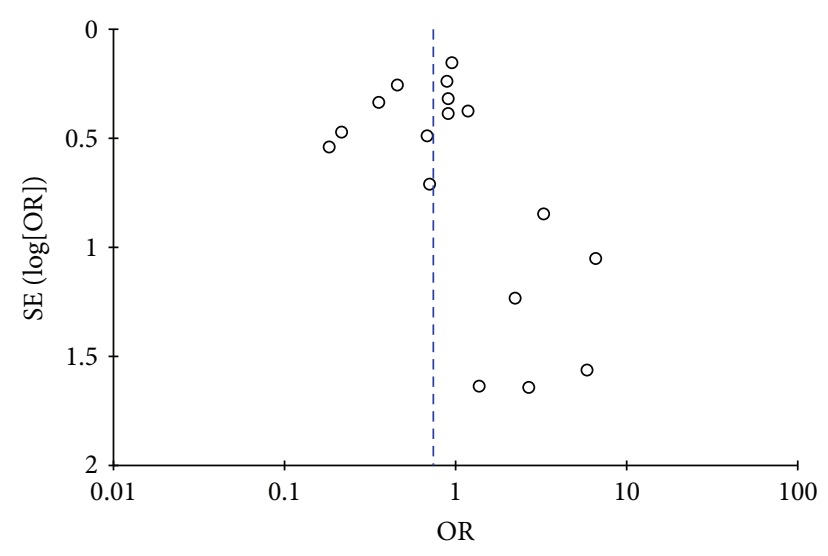

(b) rs 1544410

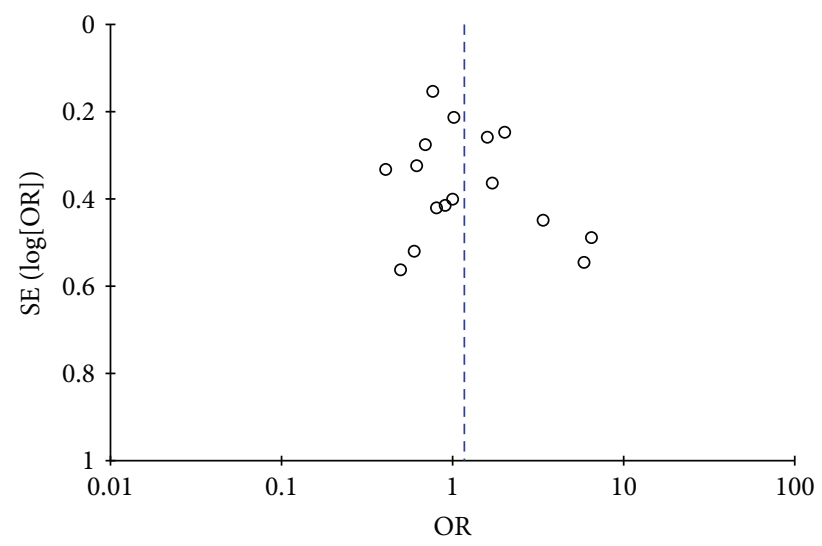

(d) rs7975232

FIGURE 3: Funnel plot of the association of VDR polymorphisms with AITD risk in homozygote comparison model.

TABLE 6: Egger's test results for the publication bias of VDR polymorphisms and AITD risk.

\begin{tabular}{lcccc}
\hline Comparison model & & \multicolumn{2}{c}{$P$ value of Egger's test } & rs2228570 \\
rs731236 & rs1544410 & 0.125 & 0.258 \\
Homozygote comparison & 0.516 & 0.626 & 0.07 & 0.274 \\
Heterozygote comparison & 0.271 & 0.521 & 0.07 & 0.283 \\
Dominant model & 0.287 & 0.444 & 0.092 & 0.130 \\
Recessive model & 0.381 & 0.933 & 0.062 & 0.186 \\
Allele comparison & 0.307 & 0.422 & & \\
\hline
\end{tabular}

increased risk of AITD in African populations (CC versus AA: $\mathrm{OR}=5.84,95 \% \mathrm{CI}: 2.00-17.02, P_{Z}=0.001$; CA versus AA: $\mathrm{OR}=3.02,95 \% \mathrm{CI}: 1.33-6.87, P_{Z}=0.008$; CC + CA versus AA: $\mathrm{OR}=3.62,95 \% \mathrm{CI}: 1.65-7.93, P_{Z}=0.001$; CC versus $\mathrm{CA}+\mathrm{AA}: \mathrm{OR}=2.79,95 \% \mathrm{CI}: 1.12-6.95, P_{Z}=0.03$; $\mathrm{C}$ versus A: $\left.\mathrm{OR}=2.29,95 \% \mathrm{CI}: 1.41-3.73, P_{Z}<0.001\right)$.

3.3. Sensitivity Analysis and Publication Bias. A sensitivity analysis showed that the pooled OR values were not substantially changed after one study deletion each time, which suggests that results of this meta-analysis were stable. As shown in Figure 3, the shape of funnel plots was symmetric. In addition, all $P$ values of Egger's test were more than 0.05 , indicating the lack of publication bias (Table 6).

\section{Discussion}

As an immune modulator, vitamin $\mathrm{D}$ is involved in the onset and development of AITD $[35,36]$. Low levels of vitamin D have been demonstrated in patients with AITD [36]. Furthermore, vitamin $\mathrm{D}$ deficiency was correlated with the duration of HT, which led to an increase in thyroid volume and in antithyroid antibodies levels [36]. Vitamin D exerts its biological effects by binding to VDR and activating VDRresponsive genes [37]. VDR is an intracellular receptor belonging to the steroid/thyroid nuclear receptor family and expressed in human immune cells including macrophages, dendritic cells, and T and B lymphocytes [35]. Therefore, the abnormal function of VDR, which is attributable to 
$V D R$ gene polymorphisms and altered transactivation, might affect the immunoregulatory and anti-inflammatory functions of vitamin D and correlate with the pathogenesis of AITD. Some studies demonstrated that genetic polymorphisms (rs731236, rs1544410, rs2228570, and rs7975232) in the VDR gene could affect the expression of VDR [38, 39]. For instance, Ogunkolade et al. found that rs2228570 in the coding region of $V D R$ gene was associated with higher VDR mRNA copy numbers [38]. Uitterlinden et al. observed that rs731236, rs1544410, and rs7975232 in the $3^{\prime}$ untranslated region of the VDR gene could affect VDR gene expression by modulating mRNA stability [39]. In view of all this, these functional polymorphisms were speculated to be associated with AITD risk. Interestingly, some epidemiological studies confirmed the speculation and found significant association between these polymorphisms and AITD risk. For instance, Long et al. and Meng et al. observed that VDR rs7975232 polymorphism was significantly associated with GD risk in Chinese populations $[14,15]$. Djurovic et al. found a significant association between VDR rs2228570 polymorphism and HT risk in Serbian populations [16]. Stefanić et al. found that VDR rs731236, rs7975232, and rs1544410 polymorphisms were associated with GD susceptibility in Eastern Croatian populations [28]. Yazici et al. observed that VDR rs731236 and rs2228570 polymorphisms were significantly associated with HT risk in a Turkish population [19]. However, other studies including genome-wide association study showed that these polymorphisms did not influence individual susceptibility to AITD $[13,18,20,23,24$, $40,41]$. These inconsistent results may be due to the fact that a single-center pilot study with small sample sizes has low statistical power to detect a true association or that the genetic background of different populations changes the effect of low-penetration polymorphisms on AITD risk. In 2013, Feng et al. tried to clarify the association by metaanalysis and found that VDR rs1544410 and rs731236 polymorphisms were significantly associated with a reduced risk of AITD, while VDR rs7975232 and rs2228570 polymorphisms were not associated with AITD risk [42]. Due to the limited number of related studies, subgroup analyses by clinical types were not conducted. Furthermore, results of recent studies were still inconsistent with that of previous meta-analysis $[13,15,16]$. Therefore, an updated analysis was performed by combining the recent studies. Results indicated that VDR rs731236 and rs2228570 polymorphisms were significantly associated with reduced risk of AITD. A further stratification analysis based on clinical types showed that VDR rs731236 and rs2228570 polymorphisms were associated only with reduced risk of HT. In a stratification analysis based on ethnicity, VDR rs731236 polymorphism was associated with a reduced risk of AITD in Asian and African populations but not in European populations. VDR rs2228570 polymorphism was associated with a reduced risk of AITD only in Asian populations. It was worthy to note that VDR rs1544410 polymorphism was associated with a reduced risk of AITD in European and African populations but has an increased risk of AITD in Asian populations. A stratification analysis by $P_{\mathrm{HWE}}$ values showed that the significant association of VDR rs2228570 polymorphism with a reduced risk of AITD was observed only in studies with $P_{\mathrm{HWE}} \leq 0.05$, which indicated that the effect of $V D R$ rs2228570 polymorphism on AITD risk needed to be interpreted cautiously.

Heterogeneity was observed in the current meta-analysis. We tried to investigate the sources of heterogeneity by a stratification analysis based on clinical types, ethnicity, and HWE, but the investigation results were not satisfactory and could not provide a reasonable explanation for the sources of heterogeneity. In view of factors affecting vitamin D levels and methodological issues, heterogeneity may result from differences in economic and public health indexes among different countries, variations in environment and climate, age and gender mismatch in published studies, and variations in diagnostic criteria for GD/HT.

Although the current results showed the statistically significant associations of $V D R$ polymorphisms with AITD risk, such associations had a small influence on the occurrence of AITD. In addition, several limitations impeding accurate assessment should be noted. Firstly, raw data such as gender, age, living style, and drug consumption could not be obtained from all included studies. Secondly, the number of studies was small in the subgroup analysis, especially in African populations. Last but not least, the present analysis did not consider the gene-gene and gene-environment interactions.

In conclusion, the present study suggested that $V D R$ rs731236, rs1544410, rs2228570, and rs7975232 polymorphisms were significantly associated with AITD risk. However, more well-designed studies, especially studies on African populations, should be performed to verify the results.

\section{Conflicts of Interest}

The authors declare that they have no competing interests.

\section{Supplementary Materials}

Table S1: genotype and allele frequency distributions of VDR polymorphisms in all included studies. (Supplementary Materials)

\section{References}

[1] W. M. G. Tunbridge, D. C. Evered, R. Hall et al., "The spectrum of thyroid disease in a community: the Whickham survey," Clinical Endocrinology, vol. 7, no. 6, pp. 481-493, 1977.

[2] J. G. Hollowell, N. W. Staehling, W. D. Flanders et al., "Serum TSH, T(4), and thyroid antibodies in the United States population (1988 to 1994): National Health and Nutrition Examination Survey (NHANES III)," The Journal of Clinical Endocrinology \& Metabolism, vol. 87, no. 2, pp. 489-499, 2002.

[3] A. Antonelli, S. M. Ferrari, A. Corrado, A. Di Domenicantonio, and P. Fallahi, "Autoimmune thyroid disorders," Autoimmunity Reviews, vol. 14, no. 2, pp. 174-180, 2015.

[4] J. Orgiazzi, "Thyroid autoimmunity," Presse Médicale, vol. 41, no. 12, pp. e611-e625, 2012. 
[5] L. Brčić, A. Barić, S. Gračan et al., "Association of established thyroid peroxidase autoantibody (TPOAb) genetic variants with Hashimoto's thyroiditis," Autoimmunity, vol. 49, no. 7, pp. 480-485, 2016.

[6] C. Durães, C. S. Moreira, I. Alvelos et al., "Polymorphisms in the TNFA and IL6 genes represent risk factors for autoimmune thyroid disease," PLoS One, vol. 9, no. 8, article e105492, 2014.

[7] Y. Ban, T. Tozaki, M. Taniyama, M. Tomita, and Y. Ban, "Association of a CTLA-4 3' untranslated region (CT60) single nucleotide polymorphism with autoimmune thyroid disease in the Japanese population," Autoimmunity, vol. 38, no. 2, pp. 151-153, 2005.

[8] X. R. Gao, C. M. Wang, W. J. Wang, G. R. Han, and J. Q. Zhang, "Serum 25-hydroxyvitamin D status in pregnant women with chronic hepatitis B virus infection," The Journal of Infection in Developing Countries, vol. 10, no. 08, p. 851, 2016.

[9] F. Baeke, T. Takiishi, H. Korf, C. Gysemans, and C. Mathieu, "Vitamin D: modulator of the immune system," Current Opinion in Pharmacology, vol. 10, no. 4, pp. 482-496, 2010.

[10] M. Willheim, R. Thien, K. Schrattbauer et al., "Regulatory effects of $1 \alpha, 25$-dihydroxyvitamin D3 on the cytokine production of human peripheral blood lymphocytes," Journal of Clinical Endocrinology and Metabolism, vol. 84, no. 10, pp. 37393744, 1999.

[11] J. W. Pike, "Vitamin D3 receptors: structure and function in transcription," Annual Review of Nutrition, vol. 11, no. 1, pp. 189-216, 1991.

[12] J. M. Valdivielso and E. Fernandez, "Vitamin D receptor polymorphisms and diseases," Clinica Chimica Acta, vol. 371, no. 1-2, pp. 1-12, 2006.

[13] S. Giovinazzo, T. M. Vicchio, R. Certo et al., "Vitamin D receptor gene polymorphisms/haplotypes and serum $25(\mathrm{OH}) \mathrm{D}_{3}$ levels in Hashimoto's thyroiditis," Endocrine, vol. 55, no. 2, pp. 599-606, 2017.

[14] X. Long, W. F. Wu, Z. Q. Hu, and Z. M. Zhou, “Association between vitamin $\mathrm{D}$ receptor polymorphisms and the risk of Graves' disease," Chinese Journal of Gerontology, vol. 35, no. 12, pp. 3254-3256, 2016.

[15] S. Meng, S. T. He, W. J. Jiang et al., "Genetic susceptibility to autoimmune thyroid diseases in a Chinese Han population: role of vitamin D receptor gene polymorphisms," Annales d'Endocrinologie, vol. 76, no. 6, pp. 684-689, 2015.

[16] J. Djurovic, O. Stojkovic, O. Ozdemir et al., "Association between FokI, ApaI and TaqI RFLP polymorphisms in VDR gene and Hashimoto's thyroiditis: preliminary data from female patients in Serbia," International Journal of Immunogenetics, vol. 42, no. 3, pp. 190-194, 2015.

[17] N. Inoue, M. Watanabe, N. Ishido et al., "The functional polymorphisms of $V D R, G C$ and $C Y P 2 R 1$ are involved in the pathogenesis of autoimmune thyroid diseases," Clinical and Experimental Immunology, vol. 178, no. 2, pp. 262269, 2014

[18] X. J. Yu and X. Q. Lan, “Association between vitamin D receptor Bsml polymorphism and the risk of Hashimoto's thyroiditis," Chinese Journal of Gerontology, vol. 30, no. 20, pp. 1845-1846, 2013.

[19] D. Yazici, D. Yavuz, O. Tarcin, S. Sancak, O. Deyneli, and S. Akalin, "Vitamin D receptor gene ApaI, TaqI, FokI and BsmI polymorphisms in a group of Turkish patients with
Hashimoto's thyroiditis," Minerva Endocrinologica, vol. 38, no. 2, pp. 195-201, 2013.

[20] L. H. Hong, "Association between vitamin D receptor polymorphisms and the risk of Hashimoto's thyroiditis," Medical Information, vol. 2, pp. 2963-2964, 2011.

[21] X. J. Huo, F. Wei, J. X. Huo, R. N. Shu, H. X. Xue, and J. H. Wei, "Association of vitamin D receptor gene BsmI polymorphism with autoimmune thyroid disease in Innermongolia people of the Han nationality," Journal of Radioimmunology, vol. 23, no. 1, pp. 72-74, 2010.

[22] W. Horst-Sikorska, M. Ignaszak-Szczepaniak, M. Marcinkowska, M. Kaczmarek, M. Stajgis, and R. Slomski, "Association analysis of vitamin D receptor gene polymorphisms with bone mineral density in young women with Graves' disease," Acta Biochimica Polonica, vol. 55, no. 2, pp. 371-380, 2008.

[23] A. Maalej, E. Petit-Teixeira, G. Chabchoub et al., "Lack of association of VDR gene polymorphisms with thyroid autoimmune disorders: familial and case/control studies," Journal of Clinical Immunology, vol. 28, no. 1, pp. 21-25, 2008.

[24] Y. Jing, X. C. Lan, X. J. Huo, H. Qiu, and X. L. Liu, “Association of VDR gene BsmI polymorphism with Hashimoto's thyroiditis," Zhejiang Academic Conference on Endocrinology, vol. 2, no. 1, pp. 124-125, 2008.

[25] M. Stefanić, S. Papić, M. Suver, L. Glavas-Obrovac, and I. Karner, "Association of vitamin D receptor gene $3^{\prime}$-variants with Hashimoto's thyroiditis in the Croatian population," International Journal of Immunogenetics, vol. 35, no. 2, pp. 125-131, 2008.

[26] W. Y. Lin, L. Wan, C. H. Tsai, R. H. Chen, C. C. Lee, and F. J. Tsai, "Vitamin D receptor gene polymorphisms are associated with risk of Hashimoto's thyroiditis in Chinese patients in Taiwan," Journal of Clinical Laboratory Analysis, vol. 20, no. 3, pp. 109-112, 2006.

[27] E. Ramos-Lopez, A. Kurylowicz, T. Bednarczuk, J. Paunkovic, C. Seidl, and K. Badenhoop, "Vitamin D receptor polymorphisms are associated with Graves' disease in German and Polish but not in Serbian patients," Thyroid, vol. 15, no. 10, pp. 1125-1130, 2005.

[28] M. Stefanić, I. Karner, L. Glavas-Obrovac et al., “Association of vitamin D receptor gene polymorphism with susceptibility to Graves' disease in Eastern Croatian population: case-control study," Croatian Medical Journal, vol. 46, no. 4, pp. 639-646, 2005.

[29] D. H. Kang, M. C. Qiu, S. Gao, M. Li, Z. H. Gao, and W. L. Su, "Association of vitamin D receptor gene polymorphisms with Graves' disease in the population of Tianjing region," Chinese Journal of Endocrinology and Metabolism, vol. 21, no. 2, pp. 128-129, 2005.

[30] Y. Ban, M. Taniyama, and Y. Ban, "Vitamin D receptor gene polymorphism is associated with Graves' disease in the Japanese population," Journal of Clinical Endocrinology and Metabolism, vol. 85, no. 12, pp. 4639-4643, 2000.

[31] R. H. Chen, C. T. Chang, H. Y. Chen, W. C. Chen, C. H. Tsai, and F. J. Tsai, "Association between vitamin-D receptor gene FokI polymorphism and Graves' disease among Taiwanese Chinese," Journal of Clinical Laboratory Analysis, vol. 21, no. 3, pp. 173-177, 2007.

[32] J. E. Collins, J. M. Heward, R. Nithiyananthan et al., "Lack of association of the vitamin $\mathrm{D}$ receptor gene with Graves' disease in UK Caucasians," Clinical Endocrinology, vol. 60, no. 5, pp. 618-624, 2004. 
[33] B. Guleryuz, F. Akin, M. T. Ata, M. M. Dalyanoglu, and S. Turgut, "Vitamin-D receptor (VDR) gene polymorphisms (TaqI, FokI) in Turkish patients with Hashimoto's thyroiditis: relationship to the levels of Vit-D and cytokines," Endocrine, Metabolic \& Immune Disorders - Drug Targets, vol. 16, no. 2, pp. 131-139, 2016.

[34] S. El Gawad, E. Samee, A. Metwali, and M. El Gawad, "Vitamin D receptor gene polymorphism and its association with 1,25dihydroxyvitamin $\mathrm{D}_{3}$ in patients with Graves disease in an Egyptian population: a pilot study," Endocrine Practice, vol. 18, no. 2, pp. 132-139, 2012.

[35] S. Kivity, N. Agmon-Levin, M. Zisappl et al., "Vitamin D and autoimmune thyroid diseases," Cellular \& Molecular Immunology, vol. 8, no. 3, pp. 243-247, 2011.

[36] G. Bizzaro and Y. Shoenfeld, "Vitamin D and autoimmune thyroid diseases: facts and unresolved questions," Immunologic Research, vol. 61, no. 1-2, pp. 46-52, 2015.

[37] A. Verstuyf, G. Carmeliet, R. Bouillon, and C. Mathieu, "Vitamin D: a pleiotropic hormone," Kidney International, vol. 78 , no. 2, pp. 140-145, 2010.

[38] B. W. Ogunkolade, B. J. Boucher, J. M. Prahl et al., "Vitamin D receptor (VDR) mRNA and VDR protein levels in relation to vitamin D status, insulin secretory capacity, and VDR genotype in Bangladeshi Asians," Diabetes, vol. 51, no. 7, pp. 2294-2300, 2002.

[39] A. G. Uitterlinden, Y. Fang, J. B. J. van Meurs, H. A. P. Pols, and J. P. T. M. van Leeuwen, "Genetics and biology of vitamin D receptor polymorphisms," Gene, vol. 338, no. 2, pp. 143156, 2004.

[40] X. Chu, C. M. Pan, S. X. Zhao et al., "A genome-wide association study identifies two new risk loci for Graves' disease," Nature Genetics, vol. 43, no. 9, pp. 897-901, 2011.

[41] M. J. Simmonds, "GWAS in autoimmune thyroid disease: redefining our understanding of pathogenesis," Nature Reviews. Endocrinology, vol. 9, no. 5, pp. 277-287, 2013.

[42] M. Feng, H. Li, S. F. Chen, W. F. Li, and F. B. Zhang, "Polymorphisms in the vitamin D receptor gene and risk of autoimmune thyroid diseases: a meta-analysis," Endocrine, vol. 43, no. 2, pp. 318-326, 2013. 


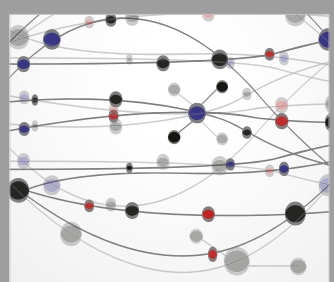

The Scientific World Journal
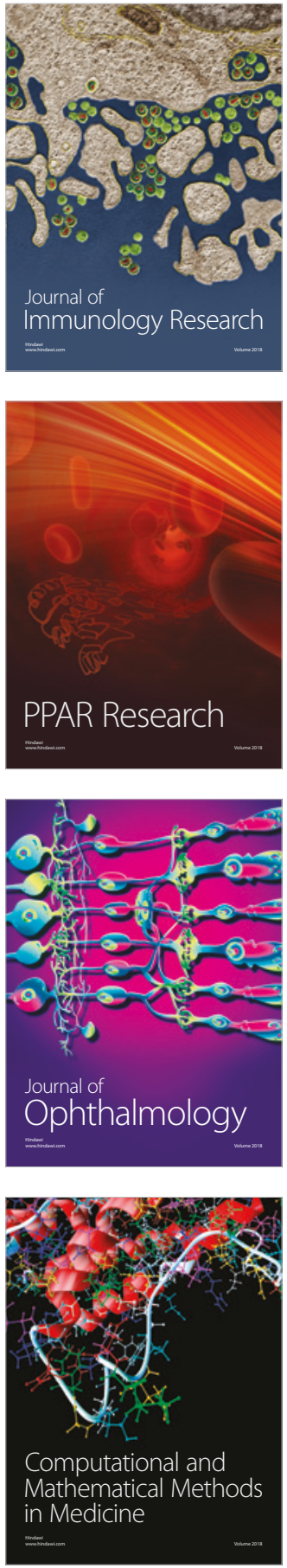

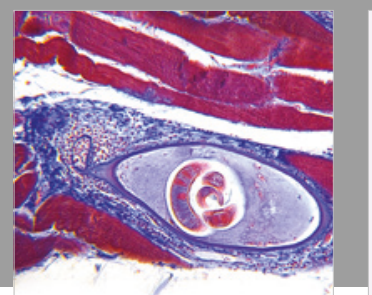

Gastroenterology Research and Practice

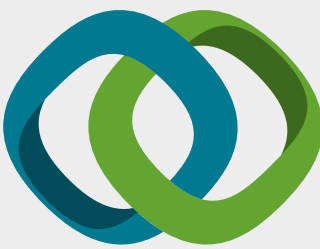

\section{Hindawi}

Submit your manuscripts at

www.hindawi.com
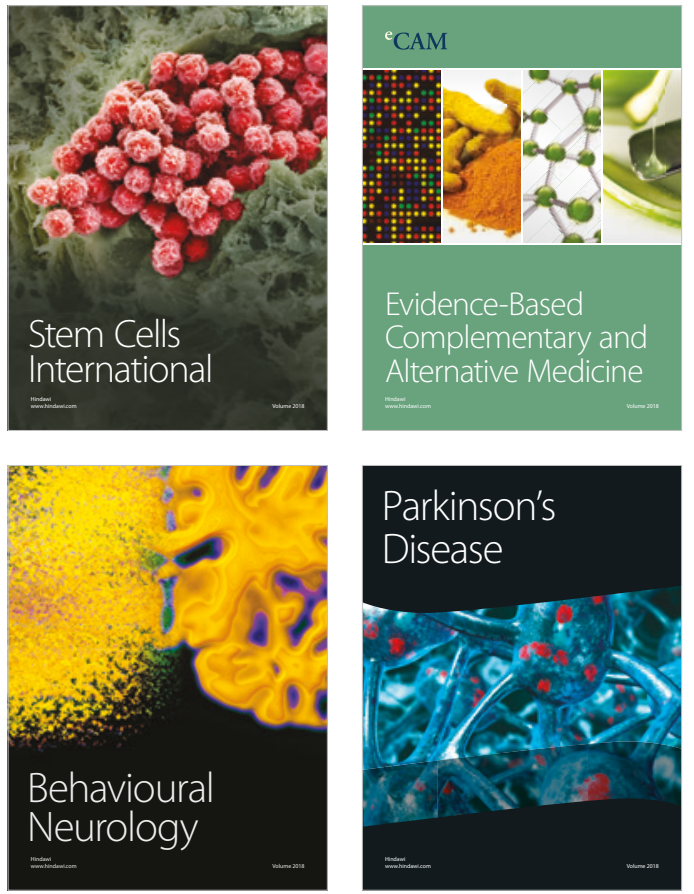

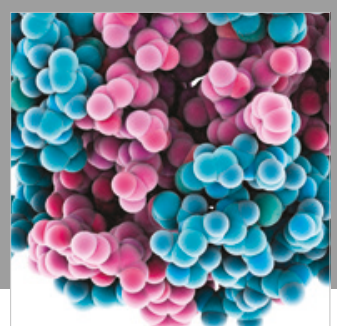

ournal of

Diabetes Research

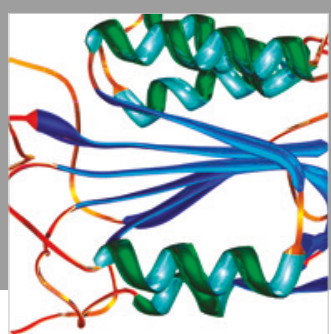

Disease Markers
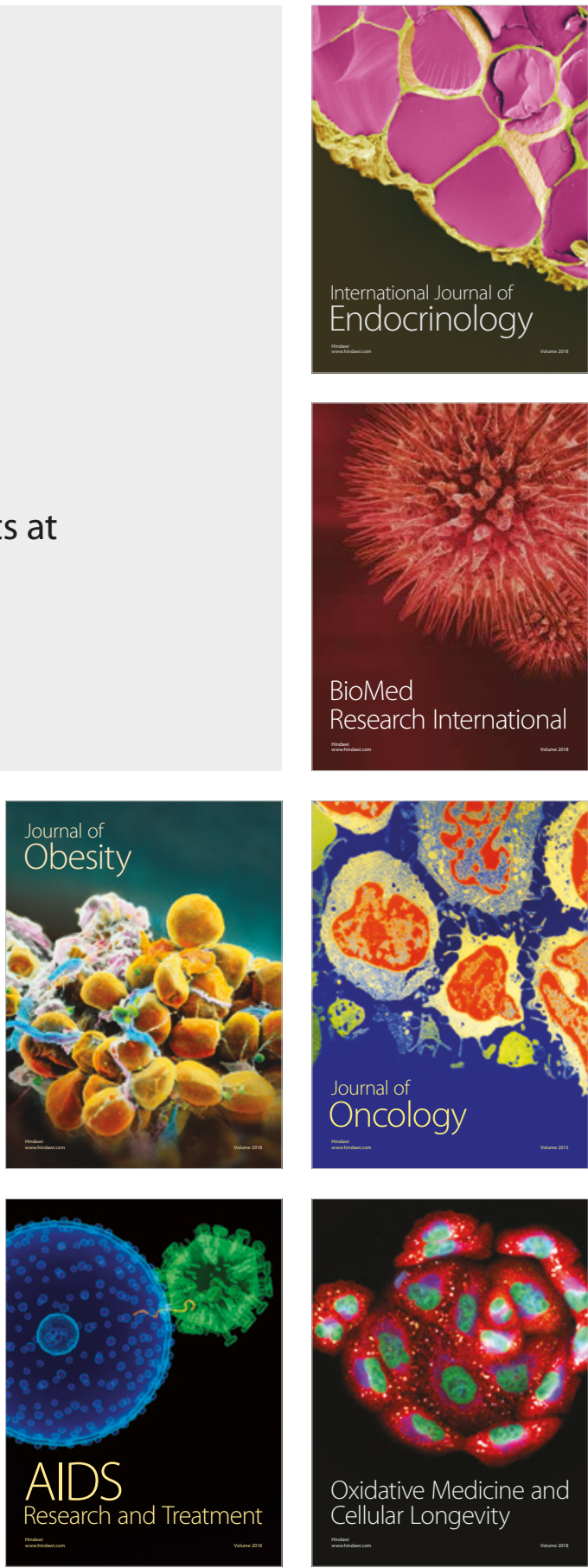